\title{
EVALUASI PROGRAM PENGEMBANGAN SUMBER DAYA MANUSIA (Studi pada Program Pelatihan di BPSDMP Kominfo Jakarta)
}

\section{EVALUATING HUMAN RESOURCE DEVELOMENT PROGRAM (Study on the Training Program in BPSDMP Kominfo Jakarta)}

\author{
Marudur P. Damanik ${ }^{1}$, Ari Cahyo Nugroho $^{2}$, Dede Mahmudah ${ }^{3}$, Erisva Hakiki \\ Purwaningsih $^{4 * *}$ \\ ${ }^{1,2,3}$ BPSDMP Kominfo Jakarta - Kementerian Komunikasi dan Informatika RI \\ Jl. Pegangsaan Timur 19B, Jakarta Pusat, Indonesia \\ ${ }^{4}$ Puslitbang SDPPPI - Kementerian Komunikasi dan Informatika RI \\ Jl. Medan Merdeka Barat No. 9 Jakarta Pusat, Indonesia \\ 1'marudur.p.d@kominfo.go.id; ${ }^{2}$ aric001@kominfo.go.id; ${ }^{3}$ dede002@kominfo.go.id; ${ }^{4}$ eris001@kominfo.go.id
}

Diterima tgl. 04/11/2020; Direvisi tgl.11/12/2020; Disetujui tgl. 14/12/2020

\begin{abstract}
This study aims to evaluate the online training program organized by the BPSDMP Kominfo Jakarta Ministry of Communication and Informatics with 3 (three) steps: evaluating reactions, learning levels, and behavior. The research was conducted with a post-positivistic approach using a mix-methods sequential exploratory design. The data was collected using online survey to 119 respondents who participated in the training. Then, 37 from these respondents were selected and interviewed by telephone. The result shows that the reaction aspect gave unsatisfactory results because there wre not enough respondents who gave good ratings. In the learning aspect, this training was succeeded in providing new knowledge, self-confidence, and motivation for participants to implement their knowledge. In evaluating the aspects of behavior and application of knowledge, there are still quite a few who have not applied and utilized their knowledge in their daily activities. The study then concluded that in general this training received a positive response and needed to be continued with some improvements. This study recommends a number of improvements for further training and human resource development programs.
\end{abstract}

Keywords: Evaluation, Training, HR Development, Internet, ICT

\begin{abstract}
ABSTRAK
Penelitian ini bertujuan untuk mengevaluasi program pelatihan daring yang diselenggarakan BPSDMP Kominfo Jakarta Kementerian Komunikasi dan Informatika dengan 3 (tiga) tahapan, yaitu mengevaluasi reaksi, tingkat pembelajaran, dan perilaku. Penelitian dilaksanakan dengan pendekatan post-positivistik menggunakan desain mix-methods sequential exploratory. Pengumpulan data dilakukan dengan metode survei daring kepada 119 responden yang menjadi peserta pelatihan. Kemudian sebanyak 37 orang dari responden tersebut dipilih dan diwawancari melalui telepon. Hasil evaluasi pada aspek reaksi belum menunjukkan hasil yang cukup memuaskan sebab tidak cukup banyak responden yang memberikan penilaian yang baik. Pada aspek pembelajaran, pelatihan ini berhasil memberikan pengetahuan baru, keyakinan diri, dan motivasi bagi peserta untuk mengimplementasikan pengetahuannya. Pada evaluasi aspek perilaku dan penerapan pengetahuan, masih cukup banyak yang belum menerapkan dan memanfaatkan pengetahuannya dalam aktivitas keseharian. Hasil penelitian ini menyimpulkan bahwa secara umum pelatihan ini mendapatkan respon yang positif dan perlu dilanjutkan dengan sejumlah perbaikan. Studi ini merekomendasikan beberapa perbaikan untuk peningkatan program pengembangan SDM kedepan.
\end{abstract}

Kata Kunci: Evaluasi, Pelatihan, Pengembangan SDM, Internet, TIK

\footnotetext{
${ }^{* *}$ Semua penulis merupakan kontributor utama
} 


\section{PENDAHULUAN}

Internet merupakan sebuah teknologi yang berkembang secara global yang saat ini tidak dapat dipisahkan dari kehidupan masyarakat. Internet banyak berkontribusi dalam aktivitas perekonomian, pekerjaan, usaha, maupun dalam aspek pendidikan. Kini lembaga-lembaga pendidikan, sekolah-sekolah dan tenaga pengajar telah memanfaatkan internet sebagai alternatif sumber bahan ajar maupun sebagai media pembelajaran (Lekawael, 2017). Kondisi ini membuat dengan sendirinya anak-anak usia sekolah pun sudah terbiasa menggunakan internet untuk kebutuhan belajarnya. Survei penetrasi internet di Indonesia tahun 2018 yang dilaksanakan oleh APJII menyebutkan bahwa rentang usia 10 - 19 atau usia sekolah memiliki persentase yang cukup tinggi dalam menggunakan internet (APJII, 2018).

Disamping bermanfaat sebagai sumber informasi, internet juga memiliki sisi negatif yang perlu menjadi perhatian. Berbagai studi yang membahas tentang efek negatif penggunaan internet menyebutkan bahwa internet dapat mengakibatkan gangguan psikologis pada anak dan remaja seperti kecanduan internet (Alimoradi et al., 2019), rasa gelisah (Mamun et al., 2019), gangguan tidur, bahkan dorongan untuk bunuh diri (Guo et al., 2018). Selain itu juga konten-konten negatif seperti pornografi, perjudian, maupun berita-berita bohong yang tersebar di internet juga berpotensi mengakibatkan perilaku menyimpang. Mudahnya proses untuk mendapatkan dan menyebarkan informasi di internet menjadi kontraproduktif yang bisa membahayakan terutama bagi pengguna internet di kalangan usia muda yang belum mampu menyaring informasi secara kritis (Diomidous et al., 2016).

Untuk mencegah dampak negatif tersebut, orang tua memiliki peranan penting dalam mendampingi anak-anaknya saat berselancar di internet. Pendampingan orang tua dalam bentuk menemani atau membantu si anak saat mencari informasi di internet terbukti mencegah anak-anak terpapar konten-konten negatif dan dampak buruk internet (Dhahir, 2018; Duerager \& Livingstone, 2012). Kualitas hubungan orang tua dan anak juga memiliki kaitan erat dengan fenomena kecanduan internet bagi remaja. Remaja yang memiliki hubungan yang dekat dengan orang tuanya memiliki kemampuan sosial yang lebih baik (De Leo \& Wulfert, 2013), sedangkan remaja yang memiliki konflik dengan orang tuanya cenderung memiliki masalah dalam perilaku, seperti sikap anti sosial maupun penyalahgunaan obat-obatan (Schneider et al., 2001). Agar pendampingan ini menjadi lebih efektif, para orang tua juga perlu mendapatkan edukasi yang sama tentang penggunaan dan pemanfaatan internet. Hal ini diperlukan agar orang tua tidak kalah pintar dengan anak-anak mereka dan agar tidak dibohongi oleh anak-anak mereka tentang penggunaan internet.

Kementerian Komunikasi dan Informatika (Kemkominfo) melalui Balai Pengembangan SDM dan Penelitian (BPSDMP) Kominfo Jakarta sebagai unit kerja Badan Litbang SDM Kemkominfo melaksanakan program pengenalan TIK bagi masyarakat. Program ini merupakan kegiatan tahunan BPSDMP Kominfo Jakarta untuk memenuhi tugas dan fungsinya dalam pengembangan SDM. Program tersebut dikemas dalam bentuk pelatihan singkat berbasis daring bagi kalangan ibu rumah tangga dan anak-anak usia sekolah yang bertujuan untuk meningkatkan literasi digital dan memperkenalkan internet sebagai produk digitalisasi serta memberikan pemahaman tentang berbagai manfaat penggunaan internet namun juga dampak negatifnya.

Dengan berkembangnya aplikasi berbasis daring untuk berbagai kebutuhan, serta meningkatnya tren perdagangan online yang saat ini ramai digunakan masyarakat, BPSDMP Kominfo Jakarta berupaya untuk bisa mengikuti tren tersebut dengan menyelenggarakan 2 (dua) pelatihan yaitu tema desain grafis dan toko daring. Untuk dapat melihat kebermanfaatannya, studi ini bertujuan untuk melakukan evaluasi agar dapat mengukur efektivitas dari pelaksanaan pengembangan SDM tersebut. Evaluasi merupakan tahapan yang wajib dilakukan untuk mengukur 
sejauh mana tingkat efektivitas dan efisiensi dari penyelenggaraan suatu program (Munajatisari, 2014).

\subsection{Pengembangan Sumber Daya Manusia}

Pengembangan Sumber Daya Manusia (SDM) merupakan salah satu unsur dalam manajemen sumber daya manusia. Sutadji (2010) mendefinisikan Pengembangan sumber daya manusia sebagai upaya penyiapan sumber daya manusia agar dapat meningkatkan kemampuan untuk melaksanakan pekerjaan yang lebih baik. Kemudian Irianto (2011) menyebutkan bahwa pengembangan SDM adalah proses peningkatan pengetahuan, keahlian (skill) dan kemampuan manusia hidup bermasyarakat. Program pengembangan SDM secara umum bertujuan agar suatu organisasi memiliki orang-orang yang berkualitas dalam mencapai tujuan organisasi untuk meningkatkan kinerja dan pertumbuhan (Armstrong, 1991). Untuk mencapai tujuan tersebut, organisasi harus dapat memastikan bahwa setiap orang memiliki pengetahuan dan keahlian dalam mencapai tingkat kemampuan yang dibutuhkan untuk melaksanakan pekerjaan mereka secara efektif. Garavan et al. (2001) menyebutkan sumber daya manusia berguna bagi organisasi karena lima hal utama, yaitu: (1) fleksibilitas dan kemampuan beradaptasi; (2) peningkatan individu; (3) kompetensi; (4) pengembangan kompetensi organisasi; dan (5) kerja individu.

SDM yang berkualitas diperoleh melalui serangkaian proses, sehingga dibutuhkan suatu program pendidikan dan pelatihan untuk mempersiapkan dan pengembangan kualitas SDM yang sesuai dengan transformasi sosial. Menurut Tilaar (1998), terdapat tiga tuntutan terhadap SDM bidang pendidikan dalam era globalisasi, yaitu: SDM yang unggul, SDM yang terus belajar, dan SDM yang memiliki nilai-nilai indigeneous. Terpenuhinya ketiga tuntutan tersebut dapat dicapai melalui pengembangan SDM. Dalam upaya pengembangan SDM hendaknya berdasarkan kepada prinsip peningkatan kualitas dan kemampuan kerja. Terdapat beberapa tujuan pengembangan SDM, di antaranya adalah: (1) meningkatkan kompetensi secara konseptual dan teknikal; (2) meningkatkan produktivitas kerja; (3) meningkatkan efisiensi dan efektivitas; (4) meningkatkan status dan karier kerja; (5) meningkatkan pelayanan terhadap klient; (6) meningkatkan moral-etis; dan (7) meningkatkan kesejahteraan. Hasibuan (2007) menjelaskan bahwa terdapat dua jenis pengembangan SDM, yaitu: pengembangan SDM secara formal dan secara informal. Pengembangan SDM secara formal yaitu SDM yang ditugaskan oleh lembaga untuk mengikuti pendidikan atau latihan, baik yang dilaksanakan oleh lembaga tersebut maupun lembaga diklat. Pengembangan SDM secara formal dilakukan karena tuntutan tugas untuk memenuhi kebutuhan saat ini maupun masa yang akan datang. Dengan demikian, jenis pengembangan ini dapat memenuhi kebutuhan kompetensi SDM yang bersifat empiris dan prediktif bagi eksistensi dan keberlanjutan lembaga. Adapun pengembangan SDM secara informal adalah pengembangan kualitas SDM secara individual berdasarkan kesadaran dan keinginan sendiri untuk meningkatkan kualitas diri sehubungan dengan tugasnya. Banyak cara yang dapat dilakuklan SDM untuk meningkatkan kemampuannya, namun jenis pengembangan ini memerlukan motivasi intrinsik yang kuat dan kemampuan mengakses sumbersumber informasi sebagai sumber belajar. (Ningrum, 2016).

Penggunaan istilah pengembangan SDM sering tumpang tindih dengan pelatihan. Padahal menurut Handoko (2001), makna pelatihan dan pengembangan SDM adalah hal yang berbeda. Menurut Mondy (2008), pelatihan merupakan serangkaian aktivitas yang dirancang guna memberi pengetahuan dan keterampilan yang dibutuhkan para pembelajar untuk dapat melaksanakan pekerjaan mereka pada saat ini. Sedangkan Dessler (2008), menyatakan bahwa pelatihan dimaksudkan untuk memberikan keterampilan yang dibutuhkan bagi karyawan baru maupun karyawan yang sudah ada dalam melakukan pekerjaannya. 
Pelatihan dimaksudkan untuk memperbaiki penguasaan berbagai keterampilan dan teknik pelaksanaan kerja tertentu, rinci dan rutin. Umumnya pelatihan dilaksanakan untuk menyiapkan tenaga kerja untuk melakukan pekerjaan-pekerjaan yang akan datang. Adapun makna pengembangan (development) memiliki ruang lingkup yang Iebih luas dalam upaya untuk memperbaiki dan meningkatkan pengetahuan, kemampuan, sikap dan sifat-sifat kepribadian. Hal ini kemudian dapat dipahami bahwa pelatihan merupakan salah satu bentuk dari pengembangan SDM.

Pelatihan dapat juga diartikan sebagai upaya yang dilakukan untuk memperbaiki kinerja seseorang pada suatu pekerjaan tertentu yang sedang menjadi tanggung jawabnya. Menurut Gomes (2003), Pelatihan Iebih terarah pada peningkatan kemampuan dan keahlian SDM organisasi yang berkaitan dengan jabatan atau fungsi yang menjadi tanggung jawab individu yang bersangkutan saat ini (current job oriented). Sasaran yang ingin dicapai dan suatu program pelatihan adalah peningkatan kinerja individu dalam jabatan atau fungsi saat ini.

Pelatihan langsung terkait dengan performansi kerja pada pekerjaan yang sekarang, sedangkan pengembangan mempunyai lingkup yang lebih luas dibandingkan dengan pelatihan. Pengembangan cenderung lebih bersifat formal, menyangkut antisipasi kemampuan dan keahlian individu yang harus dipersiapkan bagi kepentingan jabatan yang akan datang. Sasaran dan program pengembangan menyangkut aspek yang lebih luas yaitu peningkatan kemampuan individu untuk mengantisipasi perubahan yang mungkin terjadi tanpa direncanakan (unplanned change) atau perubahan yang direncanakan (Alwi, 2001).

\subsection{Evaluasi Pengembangan SDM}

Proses evaluasi dari suatu pelatihan merupakan hal yang tidak bisa dipisahkan dari siklus hidup kegiatan pengembangan SDM. Evaluasi merupakan tahapan yang wajib dilaksanakan untuk mengukur efektivitas dan efisiensi suatu pelatihan. Evaluasi pelatihan adalah usaha mengumpulkan informasi secara sistematis untuk mengukur hasil pelatihan. Evaluasi pelatihan berupaya mendapatkan informasi mengenai hasil-hasil program pelatihan, kemudian menggunakan informasi itu untuk menilai apakah pelatihan telah mencapai tujuan secara keseluruhan. Bagi penyelenggara pelatihan, evaluasi bertujuan untuk mendapatkan umpan balik dari peserta yang sangat membantu dalam memutuskan kebijakan mana yang akan diambil untuk memperbaiki pelatihan tersebut. Umpan balik yang diperoleh meliputi reaksi peserta, hasil pembelajaran peserta, perubahan perilaku di tempat kerja dan hasil yang diperoleh.

Sims (2006) menyatakan alasan program pengembangan SDM kususnya pelatihan dan pengembangan perlu dievaluasi. Beberapa alasan pentingnya mengevaluasi program pelatihan dan pengembangan adalah sebagai berikut: 1. Mengetahui kekuatan dan kelemahan program pelatihan dan pengembangan. Termasuk menentukan apakah programnya sesuai dengan tujuan pembelajaran, kualitas lingkungan belajar dan apakah penerapan pengembangan yang telah dilaksanakan benar-benar terjadi dalam pekerjaan 2. Menilai apakah isi, organisasi dan administrasi program memberikan kontribusi dalam pembelajaran dan konten dalam pengembangan SDM digunakan dalam pekerjaan. 3. Mengetahui apakah program pengembangan ini menguntungkan atau merugikan bagi peserta. 4. Mendapatkan data pemasaran dengan bertanya pada partisipan apakah mereka akan merekomendasikan program tersebut dan bagaimana tingkat kepuasan mereka terhadap program tersebut. 5. Menentukan keuntungan finansial dan biaya program 6 . Membandingkan biaya dan keuntungan program pengembangan SDM yang berbeda untuk memilih program yang terbaik.

Dari berbagai literatur telah banyak model evaluasi yang dikembangkan oleh para ahli. Biasanya model evaluasi pelatihan dibuat berdasarkan kepentingan pihak pribadi, lembaga, atau 
instansi yang berkepentingan terhadap program pelatihan yang dilaksanakan. Perkembangan konsep dan proses evaluasi pengembangan SDM dipengaruhi oleh berbagai pendapat ahli yang telah mengembangkan model-model, kerangka kerja serta sistem dan prosedur pengembangan SDM. Selain itu, evaluasi pengembangan SDM dituntut untuk obyektif dan transparan, sehingga standar dan kriteria dalam evaluasi pengembangan SDM sangat penting (Nurbiyati, 2015). Beberapa model evaluasi yang populer antara lain (Yusuf \& Suwarno, 2011):

1. Model Evaluasi CIPP (Context, Input, Process, Product). Model ini dikemukakan oleh Stufflebeam \& Shinkfield pada 1985 yang merupakan sebuah pendekatan evaluasi yang berorientasi pada pengambil keputusan (a decision oriented evaluation approach structured) untuk memberikan bantuan kepada administrator atau pengambil keputusan. Model evaluasi CIPP ini terdiri dari 4 komponen yaitu: 1) Evaluasi konteks, yang mencakup analisis masalah yang berkaitan dengan lingkungan program atau kondisi obyektif yang akan dilaksanakan; 2) Input evaluasi, yang membantu mengatur keputusan, menentukan sumber-sumber yang ada, alternatif apa yang diambil, rencana apa dan strategi apa untuk mencapai tujuan, dan bagaimana prosedur kerja untuk mencapainya; 3) Evaluasi proses, meliputi koleksi data penilaian yang telah ditentukan dan diterapkan dalam praktik pelaksanaan program. Pada dasarnya evaluasi proses untuk mengetahui sampai sejauh mana rencana telah diterapkan dan komponen apa yang perlu diperbaiki; dan 4) Evaluasi output, yaitu merupakan penilaian yang dilakukan guna melihat ketercapaian/ keberhasilan suatu pro- gram dalam mencapai tujuan yang telah ditentukan sebelumnya.

2. Model Evaluasi Abruzzese'S. Model ini dikembangkan oleh Abruzzese's pada tahun 1996, dalam bukunya "Nursing staff devel- opment; Strategies for success". Model ini berbasis pada evaluasi proses, evaluasi konten, evaluasi hasil, evaluasi dampak dan evaluasi program keseluruhan.

3. Model Evaluasi orientasi Costumer, model ini dikembangkan oleh Scriven, M. Pada tahun 1967 dalam bukunya "The methodology of evaluation" dan R. Tyler dalam "Perspective of curriculum Evaluation." Model ini melakukan evaluasi formatif dan summatif: 1) Formatif, untuk membantu mengembangkan program dan untuk meningkatkan pengembangan; 2) Summatif, untuk mengukur program yang telah dibuat dan digunakan.

4. Model evaluasi Alspach's, model ini dikembangkan oleh Alspach's pada tahun 1995. Model ini mengevaluasi: 1) Kepuasan peserta pada reaksi konten, metode penyampaian, instruktur, materi pengembangan dan lain-lain; 2) proses pembelajaran, dimana proses ini harus dapat diukur oleh perubahan kognitif, afektif dan kebiasaan psikomotor; 3) Aplikasi, merupakan implementasi hasil belajar di lingkungan kerja seperti adanya peningkatan kompetensi dalam praktik, 4) Dampak, merupakan pengaruh yang diakibatkan kemudian.

5. Evaluasi Model Kirkpatrick, yang lebih dikenal dengan Kirkpatrick Four Levels Evaluation Model yang dikembangkan oleh Donald Kirkpatrick pada tahun 1959. Evaluasi terhadap efektivitas program pelatihan menurut Kirkpatrick mencakup empat level evaluasi: 1) reaksi (reaction); 2) pembelajaran (learning); 3) perilaku (behavior); dan 4) hasil (result).

Berdasarkan analisis dari berbagai model evaluasi pelatihan di atas, studi ini menggunakan hanya beberapa dimensi evaluasi, yaitu:

1. Reaksi. Reaksi merupakan kriteria yang umum dalam mengevaluasi sebuah pelatihan (Harman \& Kemp Ellington, 2014). Mengevaluasi reaksi bertujuan untuk mendapatkan persepsi peserta terhadap berbagai aspek pada proses pelatihan, bahan pelatihan, struktur pelatihan, dan tenaga pengajar (Curado \& Martins Teixeira, 2014). Mengevaluasi reaksi 
merupakan hal yang mandatori, dan relatif murah dan mudah untuk dilaksanakan. Reaksi berhubungan dengan tingkat kepuasan peserta, dan oleh karena itu reaksi peserta harus selalu diukur untuk mendapatkan saran dan masukan peserta demi perbaikan kedepannya.

2. Learning: penilaian aspek pembelajaran bertujuan untuk mengukur perbedaan pengetahuan, keterampilan, dan sikap yang diperoleh peserta setelah pelatihan. Aspek ini juga menilai pengetahuan yang didapat oleh peserta. Mengukur aspek pembelajaran dari peserta pelatihan adalah penting karena hal ini dapat melihat pada aspek mana yang telah berubah.

3. Perilaku dan penerapan pengetahuan: penilaian aspek perilaku bertujuan untuk melihat sejauhmana penerapan pengetahuan dalam aktivitas keseharian peserta.

\section{METODE PENELITIAN}

Penelitian ini merupakan studi dengan paradigma post-poitivistik menggunakan desain mixmethods sequential exploratory, yaitu dengan menggabungkan pendekatan kuantitatif dan kualitatif (Ivankova et al., 2006). Studi ini diawali dengan mengumpulkan dan menganalisis data-data kuantitatif (numerik), dan kemudian dilanjutkan dengan pengumpulan dan analisis data kualitatif (tekstual).

Pengumpulan data dilakukan dengan metode survei, wawancara, dan observasi. Survei dilakukan secara daring (online) setelah 3 (tiga) bulan pelatihan, kepada peserta yang terdiri dari kalangan ibu rumah tangga dan anak-anak usia sekolah. Penentuan sampel pada survei ini dilakukan dengan total sampling sebanyak 141 orang. Pengiriman tautan (link) survei disampaikan melalui nomor kontak yang telah dimiliki sebelumnya. Setelah batas waktu yang ditentukan, responden yang mengirimkan jawaban hanya sebanyak 119 orang (response rate 84,4\%), dengan rincian 61 responden dari peserta desain grafis dan 58 responden dari peserta toko daring.

Pengumpulan data dilanjutkan dengan wawancara terstruktur. Wawancara dilaksanakan melalui sambungan telepon kepada 45 orang dari responden survei yang dipilih secara purposive. Kriteria informan wawancara yang dipilih adalah responden yang mengisi secara lengkap pre-test dan post-test saat pelatihan. Namun karena proses wawancara menemui sejumlah kendala, seperti nomor kontak yang tidak bisa dihubungi, responden yang menolak untuk diwawancarai, dan kendala lainnya, jumlah akhir informan wawancara adalah sebanyak 37 orang. Adapun metode observasi dilaksanakan dengan mengamati rekaman pelatihan untuk melihat gambaran sikap, perilaku, motivasi dan interaksi responden saat pelatihan

Teknik pengolahan data menggunakan metode statistik distribusi dan koding. Penilaian terhadap reaksi peserta diukur dengan metode rating dengan rentang bintang 1 ( $\star$ ) hingga bintang $5(\star \star \star \star \star)$, dimana $\star$ merupakan penilaian terendah dan $\star \star \star \star \star$ merupakan penilaian tertinggi. Untuk penilaian pada aspek pembelajaran dan perilaku, pengukuran menggunakan skala likert.

Adapun metode analisis data dalam penelitian ini adalah metode analisis statistik deskriptif, naratif dan tematik. Analisis tematik merupakan sebuah metode untuk mengidentifikasi, menganalisis dan memaparkan pola-pola (tema) yang terdapat pada data, dan dapat menginterpretasikan aspek beragam dari topik penelitian (Boyatzis, 1998). Pada analisis tematik, informasi diurutkan berdasarkan tema, dimana dalam hal ini mengacu pada ide-ide dan topik-topik yang diperoleh dalam analisis material dan menghasilkan lebih dari satu kelompok data. Tema yang sama digambarkan oleh kata yang berbeda, terdapat dalam konteks berbeda, atau diekspresikan oleh orang yang berbeda (Hayes, 1997). 


\section{HASIL DAN PEMBAHASAN}

\subsection{Gambaran Program Pengembangan SDM di BPSDMP Kominfo Jakarta}

Program pengembangan SDM di BPSDMP Kominfo Jakarta merupakan program tahunan yang menjadi salah satu tugas pokok dan fungsi BPSDMP Kominfo Jakarta. Dalam nomenklaturnya, program ini dinamakan Program Pengenalan TIK bagi masyarakat yang diselenggarakan dalam bentuk pelatihan singkat. Program pelatihan ini sedianya diselenggarakan secara tatap muka di galeri internet BPSDMP Kominfo Jakarta. Sejak mewabahnya COVID-19 di Indonesia pada awal tahun 2020, pola penyelenggaraan pelatihan berubah menjadi berbasis daring (online). Pelatihan dilaksanakan terdiri atas dua tema yaitu pelatihan desain grafis, dan pelatihan toko daring.

Pelatihan desain grafis merupakan program pelatihan terkait penggunaan aplikasi desain grafis dan animasi sederhana. Instruktur yang dalam pelatihan ini adalah Ibu Yosephine dari Relawan TIK Jakarta. Peserta pelatihan desain grafis terdiri dari kalangan ibu rumah tangga dan siswa sekolah setingkat SD, SMP, dan SLTA. Secara garis besar, pelatihan desain grafis bertujuan untuk melatih peserta agar dapat mendesain objek-objek grafis dan animasi sebagai media penyampaian informasi menggunakan aplikasi komputer, misalnya pembuatan poster, infografis, spanduk (banner), lembar pengumuman, atau flyer, yang dapat dimanfaatkan pada aktivitas sekolah ataupun dalam aktivitas sehari-hari. Selain itu dalam pelatihan ini juga mengajarkan peserta bagaimana membuat animasi sederhana. Perangkat lunak dan alat bantu yang digunakan dalam pelatihan adalah aplikasi berbasis online yaitu CANVA untuk desain grafis, dan SCRATCH untuk pembuatan animasi.

Adapun pelatihan toko daring merupakan program pelatihan yang mengajarkan tentang bagaimana berjualan di toko daring, meliputi penggunaan aplikasi e-commerce dan marketplace serta memaksimalkannya untuk menjual produk-produknya secara online. Sasaran peserta pelatihan ini adalah kalangan ibu rumah tangga. Kedua pelatihan ini telah diselenggarakan dalam dua gelombang, dimana gelombang I dilaksanakan pada bulan Juni 2020 dan gelombang II telah dilaksanakan pada Juli 2020.

\subsection{Evaluasi Reaksi Peserta terhadap Program Pelatihan}

Evaluasi pada aspek reaksi bertujuan untuk menilai pelaksanaan pelatihan. Pada aspek ini, fokus penilaian adalah kejelasan instruktur dalam menyampaikan materi, kelengkapan materi, kejelasan suara dan gambar, dan penilaian pelatihan secara keseluruhan.

a) Evaluasi Reaksi Pelatihan Desain Grafis

Pada aspek kejelasan instruktur dalam menyampaikan materi pelatihan, sebagian besar peserta pelatihan desain grafis $(58 \%)$ memberikan penilaian yang tinggi/baik namun ada pula yang memberikan penilaian sedang $(\star \star \star)$ dengan persentase sebesar $30 \%$, dan penilaian rendah/tidak baik ( $\star$ dan $\star \star$ ) dengan persentase sebesar $13 \%$. Kejelasan dalam penyampaian materi tidak hanya karena instruktur itu sendiri, namun juga dipengaruhi oleh kualitas jaringan yang dimiliki oleh responden, seperti yang disampaikan salah satu informan wawancara:

"Instrukturnya asyik, cara penyampaiannya jelas dan mudah dimengerti. Modulnya mudah dimengerti, tapi suaranya kurang jelas dan terputus-putus, mungkin karena signalnya jelek, kalau tidak pakai handset tidak jelas. Tapi kalau gambarnya bagus dan bersih. Selain itu waktu pelatihan kurang lama, perlu ditambah." (Guru sekolah dasar) 
Terkait kelengkapan dan bobot materi yang dibawakan, mayoritas peserta memberikan penilaian yang baik dengan persentase sebesar 58\%. Namun ada pula yang memberikan penilaian sedang dengan persentase sebesar $25 \%$, dan penilaian rendah dengan persentase sebesar $18 \%$. Ini artinya responden sudah cukup puas dengan kelengkapan dan bobot materi yang dibawakan oleh instruktur.

Adapun terkait kejelasan suara dan gambar saat pelatihan, sebagian besar peserta memberikan penilaian yang baik dengan persentase sebesar 51\%. Namun ada pula yang memberikan penilaian sedang dengan persentase sebesar $34 \%$, dan penilaian rendah dengan persentase sebesar $15 \%$. Ini artinya responden sudah cukup puas dengan kejelasan suara dan gambar saat pelatihan yang dibawakan oleh instruktur.

Secara keseluruhan, mayoritas peserta pelatihan desain grafis $(64 \%)$ memberikan penilaian yang baik, sedangkan yang memberikan nilai rendah sebesar $11 \%$. Ini artinya pelatihan desain grafis yang dilakukan oleh BPSDMP Kominfo Jakarta sudah dirasakan tepat oleh responden. Hasil evaluasi reaksi diperlihatkan pada Gambar 1.

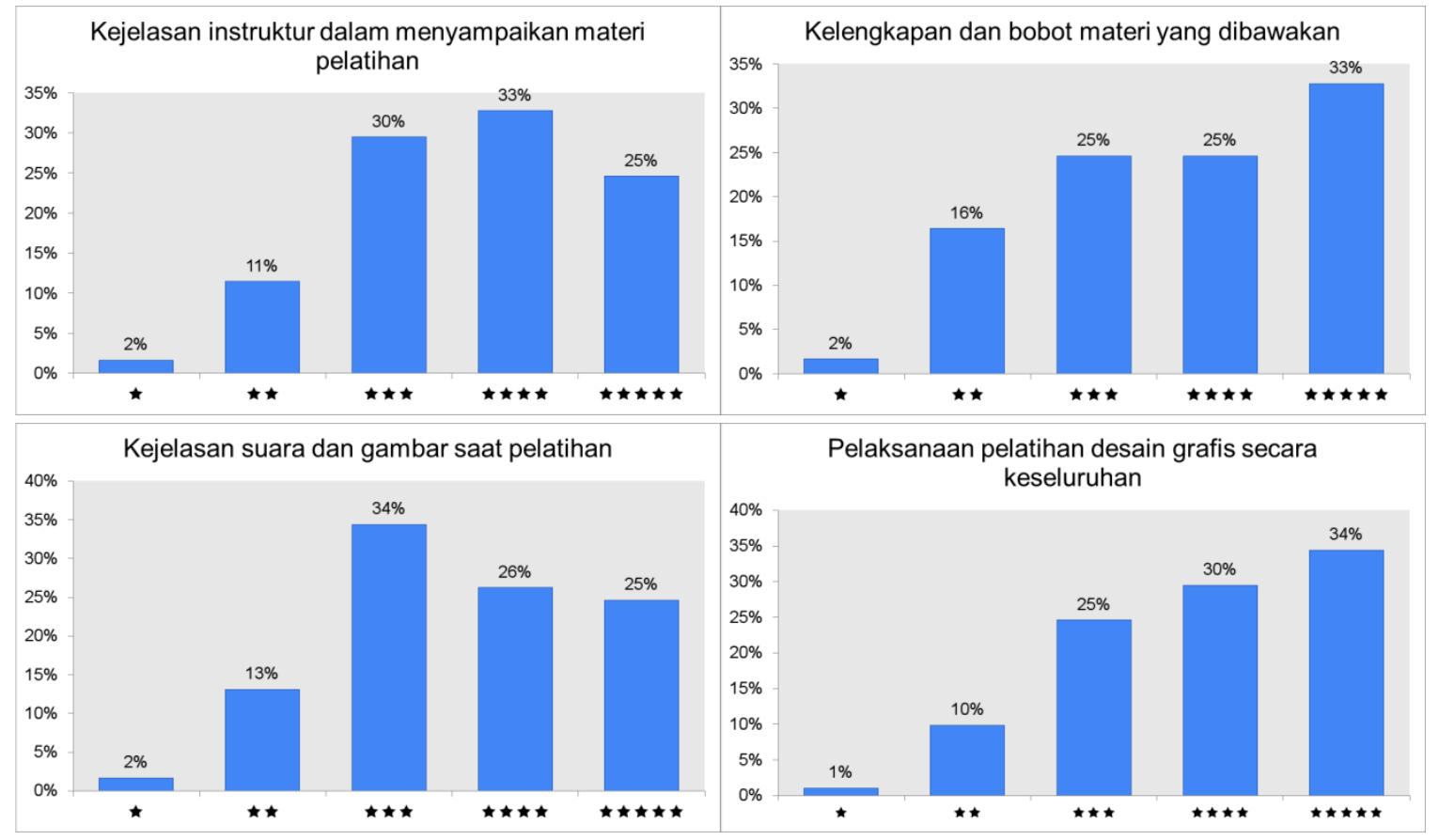

Gambar 1. Evaluasi Reaksi Peserta Terhadap Pelatihan Desain Grafis

\section{b) Evaluasi Pelatihan Toko Daring}

Hasil evaluasi reaksi peserta pelatihan toko daring ditunjukkan pada Gambar 2. Penilaian reaksi peserta terkait kejelasan instruktur dalam menyampaikan materi pelatihan menunjukkan sebagian besar peserta (48\%) memberikan nilai sedang $(\star \star \star)$, sedangkan $41 \%$ peserta yang memberikan memberikan penilaian yang baik $(\star \star \star \star$ dan $\star \star \star \star \star)$. Selain itu ada pula yang memberikan penilaian rendah ( $\star$ dan $\star \star$ ) dengan persentase sebesar $11 \%$.

Dalam hal kelengkapan dan bobot materi yang dibawakan, mayoritas peserta memberikan penilaian yang baik dengan persentase sebesar $46 \%$. Namun ada pula yang memberikan penilaian sedang dengan persentase sebesar $40 \%$, dan penilaian rendah dengan persentase sebesar $14 \%$. Hal ini dapat disimpulkan bahwa bobot materi-materi pelatihan masih perlu dikembangkan dan disempurnakan 
Terkait kejelasan suara dan gambar saat pelatihan, $44 \%$ peserta memberikan penilaian yang baik. Namun ada pula yang memberikan penilaian sedang dengan persentase sebesar $37 \%$, dan penilaian rendah dengan persentase sebesar $19 \%$.

Adapun pada penilaian pelatihan toko daring secara keseluruhan, $49 \%$ peserta memberikan penilaian yang baik. Sedangkan yang memberikan penilaian sedang dengan persentase sebesar $41 \%$, dan penilaian rendah dengan persentase sebesar $10 \%$.

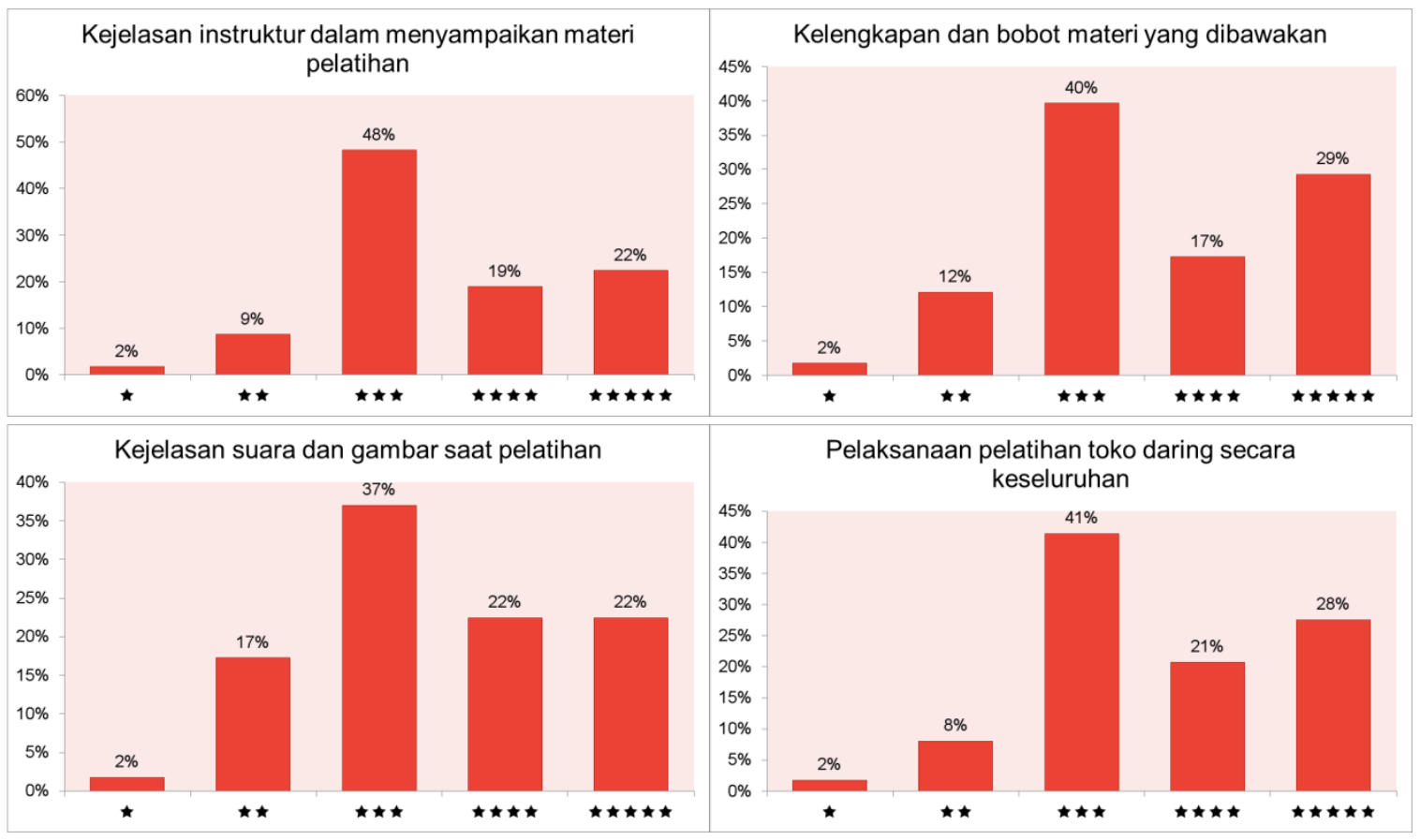

Gambar 2. Evaluasi Reaksi Peserta terhadap Pelatihan Toko Daring

\subsection{Evaluasi Pembelajaran (Learning) Peserta Pelatihan}

Hasil evaluasi pembelajaran (learning) peserta pelatihan ditunjukkan pada Gambar 3, 4, dan 5. Evaluasi aspek pembelajaran diukur dengan beberapa indikator, yaitu: 1) mendapat pengetahuan baru; 2) materi mudah dipraktikkan; 3) keyakinan dan percaya diri; dan 4) termotivasi.

Dalam hal peserta mendapatkan pengetahuan baru, mayoritas responden menjawab setuju dan sangat setuju. Hal ini terlihat dari persentase jawaban responden pada pelatihan toko daring $(85 \%)$ dan desain grafis (79\%), hanya sebagian kecil responden saja yang memberikan jawaban tidak setuju dan sangat tidak setuju. Hasil jawaban ini menunjukkan pelatihan ini berhasil memberikan pengetahuan baru bagi peserta pelatihan.

Dari wawancara mendalam yang dilakukan kepada beberapa informan diketahui sebagian besar peserta pada pelatihan desain grafis telah mengetahui aplikasi Canva yang digunakan untuk desain grafis, namun pada umumnya mereka belum pernah menggunakan secara detail. Sedangkan aplikasi Scratch yang digunakan untuk animasi sederhana, peserta baru mengetahuinya. Dari pelatihan yang diadakan oleh BPSDMP Kominfo Jakarta ini mereka akhirnya dapat mengetahui lebih dalam tentang fitur-fitur yang ada dalam aplikasi CANVA, seperti penuturan salah satu informan:

"Untuk aplikasi canva memang saya sebelumnya sudah tahu dan menggunakannya, sedangkan aplikasi scratch saya memang baru mengetahuinya. saya sangat tertarik dengan canva dan scratch untuk mendapatkan pengetahuan tambahan." (Peserta desain grafis, Pelajar SMK) 
Hal yang sama juga terjadi pada pelatihan toko daring. Hasil wawancara menemukan bahwa sebagian besar informan belum mengetahui tentang proses penjualan melalui toko daring, dan belum mempraktikkannya. Salah satu informan menyebutkan bahwa dirinya belum mengetahui pelatihan toko daring sebelumnya, dan baru mengetahuinya setelah mengikuti pelatihan ini. Senada dengan pendapat diatas, peserta lain dari kalangan ibu rumah tangga menyebutkan bahwa dirinya belum mengetahui materi yang diajarkan, dan seluruh materi yang didapat merupakan hal baru baginya. Media sosial selama ini digunakan sebagai sarana hiburan saja, dan baru mengetahui bahwa bisa digunakan untuk menambah penghasilan dengan berjualan online.

Namun ada pula peserta yang sebelumnya sudah mengetahui toko daring, namun dengan jumlah yang sedikit. Bagi peserta tersebut, mengikuti pelatihan ini bertujuan untuk menambah pengetahuan dan hal-hal baru dalam berjualan di toko daring, seperti hasil wawancara berikut:

"Saat ini saya bekerja sebagai guru pengajar bahasa indonesia untuk ekspatriat. saya berdomisili di Jakarta. untuk pelatihan ini saya mengikuti dari awal sampai akhir pelatihan. memang untuk aplikasi toko daring ini sebelumnya saya sudah mengetahuinya. Saya mengikuti pelatihan ini karena menginginkan penambahan pengetahuan. atau upgrade ilmu pengetahuan. saya sudah mempelajari tutorial toko dari melalui youtube tapi tidak jadi-jadi produknya sampai sekarang. Sebelumnya saya sudah mengetahui cara membuat toko online dari youtube. namun setelah pelatihan saya menjadi lebih paham apa yang harus saya lakukan. langkah demi langkah untuk membuat toko online.." (Peserta toko daring, guru Bahasa Indonesia untuk para ekspatriat).

Beberapa peserta juga merasakan penambahan wawasan yang luas mengenai transaksi online melalui toko daring. Peserta yang pada awalnya melakukan penjualan secara manual, setelah pelatihan, dapat melakukan penjualan secara online melalui Facebook, Instagram, Shopee, Tokopedia dan Instagram, bahkan Whatsapp.

“...Seperti pemasaran di medsos ialah hal baru. Namun penjualan di instagram sudah pernah dengar dari teman...". (Peserta toko daring, Ibu rumah tangga)

Peserta berpendapat adanya peningkatan yang signifikan dalam penambahan atau upgrade wawasan dan ilmu pengetahuan. Ada pula peserta yang sudah mempelajari toko online melalui Youtube, namun tidak berhasil, hingga setelah mengikuti pelatihan ini responden berhasil mewujudkan toko daringnya. Hampir sebagian besar responden menyatakan bahwa sosial media hanya digunakan sebagai sarana hiburan saja.

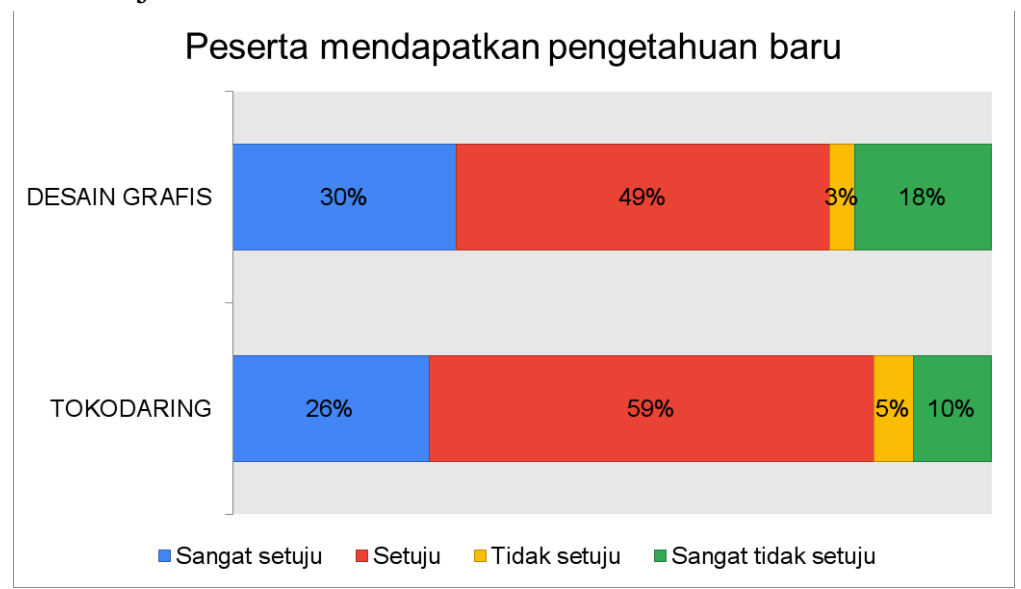

Gambar 3. Jawaban Responden Apakah Mendapatkan Pengetahuan Baru dari Pelatihan 
Terkait tingkat kemudahan materi, sebagian besar peserta juga setuju dan sangat setuju bahwa materi pelatihan mudah dipahami dan dipraktikkan. Hal ini terlihat dari persentase jawaban peserta pelatihan toko daring $(86 \%)$ dan desain grafis $(60 \%)$. Dari wawancara informan pelatihan desain grafis, Umumnya informan menyebutkan bahwa penggunaan aplikasi CANVA dianggap mudah untuk dipraktekkan bila dibandingkan dengan aplikasi Scratch. Hal ini disebabkan karena aplikasi CANVA memudahkan pengguna dengan fitur yang mudah dipahami, dapat diakses melalui telepon seluler serta paparan dan modul dari instruktur pelatihan yang mudah dipahami. Sedangkan aplikasi scratch dinilai tidak mudah dalam penggunaannya, karena fitur-fiturnya lebih sulit untuk dipahami.

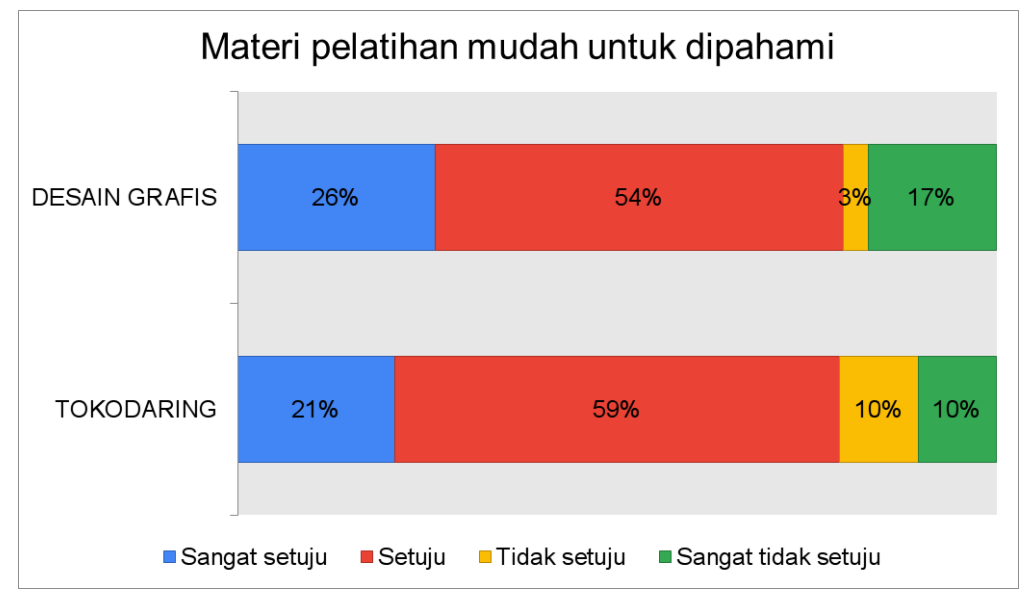

Gambar 4. Jawaban Responden Terhadap Kemudahan Materi Pelatihan

Terkait keyakinan peserta dan kepercayaan diri untuk mempraktekkan, mayoritas jawaban responden adalah setuju dan sangat setuju pada pelatihan toko daring dan desain grafis. Hal ini terlihat dari persentase jawaban desain grafis (79\%) dan toko daring (81\%). dan hanya sebagian kecil responden saja yang memberikan jawaban tidak setuju dan sangat tidak setuju. Mengenai peserta semakin termotivasi untuk mempraktikkan, tampak dominasi jawaban responden adalah setuju dan sangat setuju pada pelatihan toko daring dan canva. hal ini terlihat dari persentase jawaban desain grafis (79\%) dan toko daring (80\%), hanya sebagian kecil responden saja yang memberikan jawaban tidak setuju dan sangat tidak setuju.

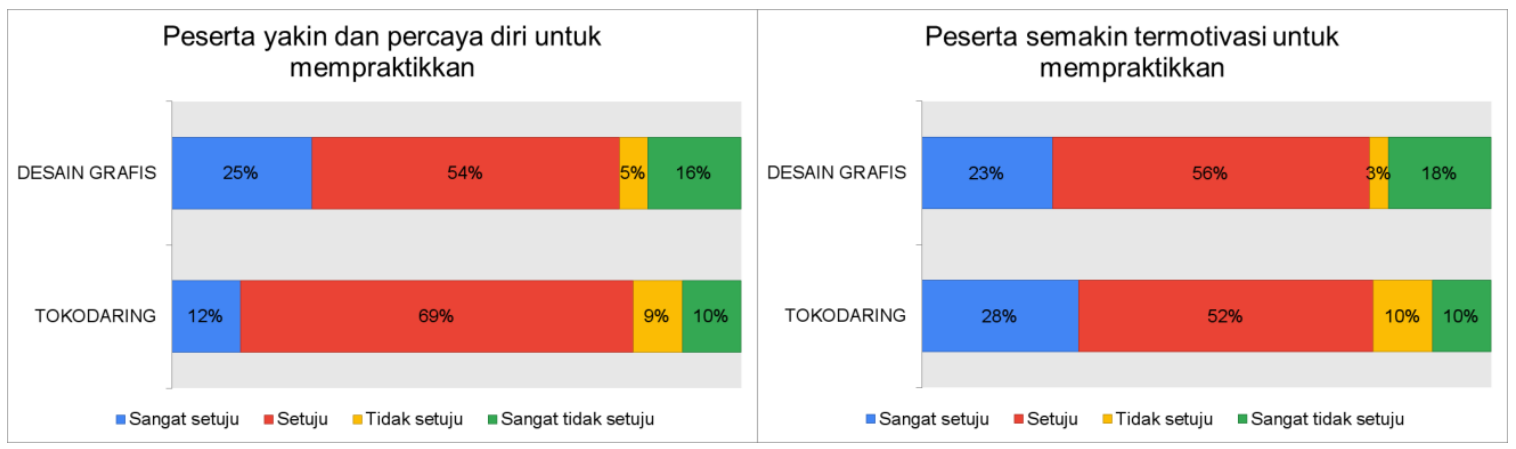

Gambar 5. Jawaban Responden Terkait Aspek Pembelajaran

\subsection{Evaluasi Perilaku dan Penerapan Pengetahuan}

Evaluasi selanjutnya mengukur apakah pengetahuan yang didapat saat pelatihan telah diterapkan. Pada pelatihan desain grafis, peserta ditanyakan apakah peserta sudah membuat desaindesain grafis dan apakah sudah menggunakan desain yang dibuat dalam aktivitas belajar maupun dalam pekerjaannya. Hasil survei daring kepada peserta pelatihan desain grafis menunjukkan 
sebagian responden (49\%) menyatakan masih sedikit desain yang dihasilkan, dan $25 \%$ responden menyatakan belum menerapkan atau membuat desain grafis sama sekali. Sedangkan yang menyatakan sudah banyak dan sangat banyak membuat desain grafis hanya sebanyak $26 \%$.

Adapun dalam penggunaan desain-desain yang telah dibuat, $34 \%$ responden menyatakan belum pernah menggunakan desain grafis yang dibuat dalam aktivitas belajar, 33\% responden menyatakan desain grafis jarang digunakan, dan 33\% lainnya menyatakan sering dan sangat sering menggunakan desain grafis dalam aktivitas belajar maupun aktivitas keseharian lainnya.

Dari pendalaman melalui wawancara ditemukan bahwa sebagian informan sudah memanfaatkannya. Salah satu informan dari kalangan ibu rumah tangga yang juga berprofesi sebagai guru sudah menggunakan aplikasi CANVA untuk membuat bahan ajar, tidak hanya untuk diri sendiri tapi juga membantu rekan guru lainnya dalam menyusun materi yang akan ditampilkan kepada para peserta didiknya. Informan yang berasal dari kalangan pelajar, beberapa diantaranya juga sudah memanfaatkan aplikasi CANVA dalam menyusun tugas yang diperoleh selama pembelajaran online maupun untuk mengedit photo untuk keperluan pribadi.

"Setelah pelatihan semakin bisa menggunakan CANVA sehingga saat update status di medsos dengan foto/gambar hasil edit dengan CANVA banyak yang minta diajarkan CANVA. Sehingga pelatihan ini sangat bermanfaat menambah ilmu untuk edit foto/gambar." (Peserta desain grafis, Pelajar SMP)

Beberapa informan yang belum memanfaatkan aplikasi desain grafis disebabkan karena masih ada belum begitu memahami dan belum percaya diri untuk mendesain dengan aplikasi CANVA serta perlu berlatih kembali karena pada saat pelatihan terganggu masalah teknis dan fitur aplikasi yang tidak tersedia di telepon selular informan tersebut. Disamping itu ada pula informan yang merasa belum sempat untuk mencoba, karena adanya kesibukan lain yang harus dilakukan. Hasil evaluasi pada aspek penerapan pengetahuan ditunjukkan pada Gambar 6.

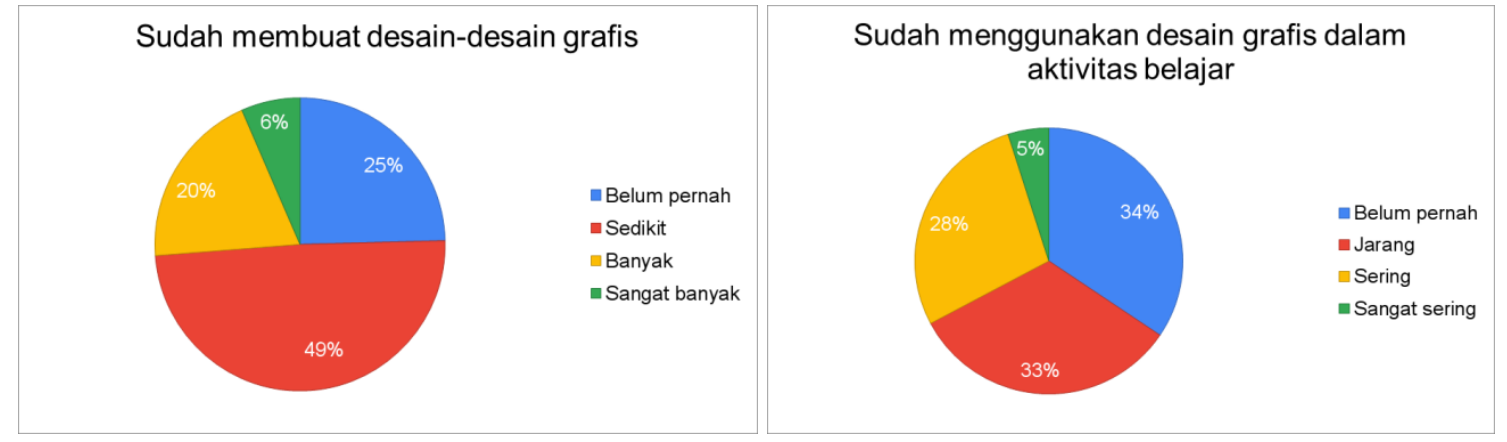

Gambar 6. Hasil Evaluasi Aspek Perilaku dan Penerapan Pengetahuan pada Pelatihan Desain Grafis

Untuk pelatihan toko daring, aspek penerapan pengetahuan digali melalui pertanyaan apakah peserta sudah membuka akun toko daring dan sudah mengunggah produknya setelah pelatihan. Dari hasil jawaban responden ditemukan bahwa sebagian besar responden (55\%) belum membuka akun toko daring. Terdapat $23 \%$ responden yang sudah membuka akun toko daring setelah mengikuti pelatihan, dan $22 \%$ responden sudah memiliki akun sebelum mengikuti pelatihan. Disamping itu dari survei ini juga diketahui bahwa $46 \%$ responden belum pernah mengunggah produknya di toko daring. Sementara hanya $14 \%$ yang menyatakan sudah sering mengunggah produknya, dan ada $40 \%$ yang menyatakan jarang mengunggah produknya. Beberapa alasan yang disampaikan informan yang belum membuka akun maupun belum mengunggah produknya adalah karena belum sempat melaksanakannya, atau masih ada kesibukan lain sehingga belum dapat 
membuat akun ataupun mengunggah produk. Disamping itu pula ada informan lain yang menyebutkan masih belum yakin untuk membuat akun, karena masih kurang memahami. Hasil survei evaluasi pada aspek penerapan pengetahuan pelatihan toko daring ditunjukkan pada Gambar 7.

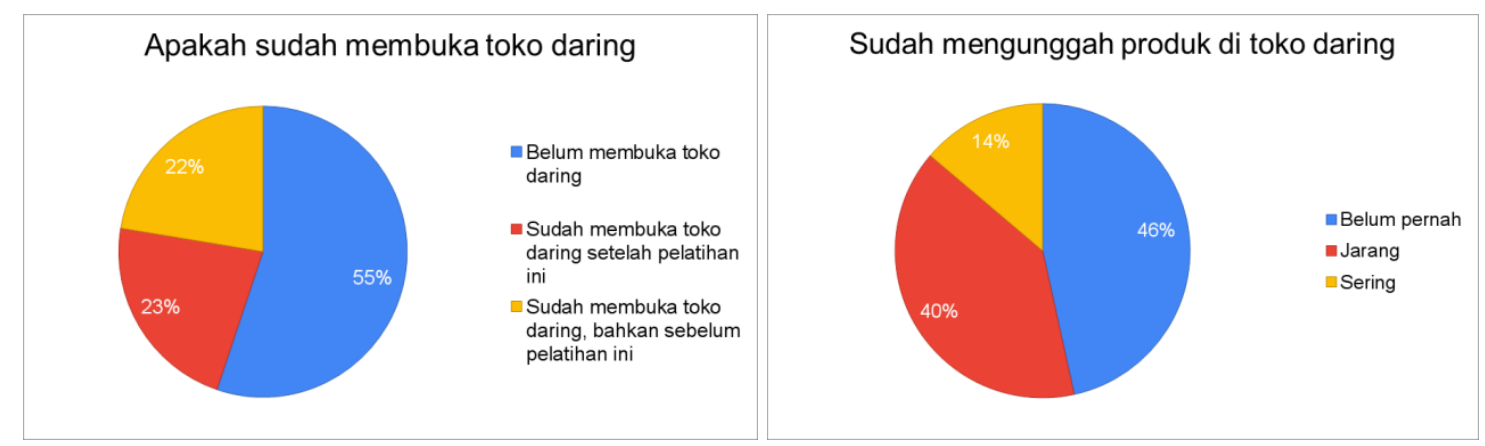

Gambar 7. Hasil Evaluasi Aspek Penerapan Pengetahuan pada Pelatihan Toko Daring

\subsection{Diskusi dan Pembahasan}

Dari hasil evaluasi reaksi peserta pelatihan diperoleh hasil yang belum cukup memuaskan. Pada pelatihan desain grafis, dari semua aspek reaksi yang dinilai hanya pada penilaian secara keseluruhan respon baik dan sangat baik dapat mencapai lebih dari $60 \%$, sedangkan pada aspek lainnya hanya berkisar 50\%. Reaksi peserta pada pelatihan toko daring malah mendapat penilaian yang lebih rendah. Kesemua aspek reaksi, yaitu kejelasan instruktur, kelengkapan dan bobot materi, kejelasan suara, dan penilaian secara keseluruhan, penilaian baik dan sangat baik tidak ada yang mencapai $50 \%$.

Dari beberapa saran dan masukan yang ditemukan dalam survei dan wawancara, pelatihan desain grafis maupun toko daring memang memiliki beberapa kelemahan. Pelatihan yang diselenggarakan BPSDMP Kominfo Jakarta ini lebih kepada pengenalan dalam menggunakan aplikasi-aplikasi daring, sehingga materi-materi yang disajikan juga adalah materi yang cukup mendasar. Disamping itu durasi pelatihan yang selama 120 menit dirasa sangat kurang bagi peserta untuk mendapatkan pengetahuan sekaligus mempraktikkannya pada saat pelatihan. Kelemahankelemahan ini sangat memungkinkan yang menjadikan peserta memberikan nilai yang tidak terlalu memuaskan. Oleh karena itu yang menjadi pertimbangan untuk perbaikan kedepan adalah perlunya peningkatan materi pelatihan dan perbaikan pada cara instruktur mengajar.

Meskipun dari reaksi responden belum cukup memuaskan, pelatihan ini berhasil memberikan pengetahuan baru bagi peserta pelatihan yang terlihat dari mayoritas jawaban responden. Hal ini juga sejalan dengan tingkat kemudahan materi untuk dapat dilaksanakan. Disamping itu, melalui pelatihan ini juga peserta merasakan lebih percaya diri dan motivasi untuk mempraktikkan pengetahuan. Hal ini dapat diartikan bahwa bagi peserta desain grafis, pelatihan ini memotivasi dan memberikan keyakinan bagi peserta untuk dapat menghasilkan desain-desain grafis yang dapat dimanfaatkan dalam aktivitas sehari-hari, baik dalam belajar maupun bekerja. Sedangkan untuk peserta toko daring, pelatihan ini mampu meyakinkan peserta dan memotivasi mereka untuk dapat berjualan di toko daring.

Selanjutnya penilaian pada aspek penerapan pengetahuan, sebagian besar peserta juga belum menerapkan pengetahuan yang diperoleh dari pelatihan, terutama pada pelatihan toko daring dimana sebagian besar peserta belum membuat akun atau mengunggah produk. Hal ini perlu menjadi perhatian penyelenggara, agar kedepannya kegiatan ini dapat memberikan hasil secara langsung setelah berakhir sebagai luaran (output) pelatihan, misalnya untuk peserta desain grafis, 
peserta diharapkan bisa membuat sebuah produk desain, atau untuk peserta toko daring, diharapkan saat selesai pelatihan seluruh peserta sudah memiliki akun toko daring dan mengunggah minimal satu produknya. Disamping itu pemilihan calon peserta juga perlu diseleksi lebih tepat sasaran untuk dapat menjaring peserta yang benar-benar serius dan membutuhkan pengetahuan yang diajarkan.

\section{PENUTUP}

Evaluasi merupakan salah satu rangkaian yang penting dijalankan dalam suatu siklus hidup program pengembangan SDM. Selain untuk dapat mengukur efektivitas dan efisiensi suatu pelatihan, evaluasi juga bertujuan untuk mendapatkan masukan sehingga bisa mengidentifikasi faktor-faktor keberhasilan maupun kekurangan dari sebuah pelatihan. Hal ini tentunya penting untuk menjadi dasar perbaikan program-program pelatihan selanjutnya. Demikian pula halnya program pengembangan SDM yang diselenggarakan BPSDMP Kominfo Jakarta perlu dievaluasi untuk melihat apakah pelatihan telah berjalan sesuai yang diharapkan atau justru perlu mendapatkan perubahan desain pelatihan untuk perbaikan kedepan. Pelaksanaan evaluasi ini dilakukan dengan 3 (tiga) tahap yaitu mengevaluasi reaksi, aspek pembelajaran, dan penerapan pengetahuan.

Secara umum hasil evaluasi menunjukkan adanya penilaian yang positif dari peserta. Peserta mengakui mendapatkan banyak manfaat dari pelatihan yang diselenggarakan, dengan memperoleh pengetahuan dan keterampilan dasar pada bidang desain grafis dan toko daring meskipun beberapa dari peserta telah mengetahui materi yang diajarkan. Melalui pelatihan ini peserta juga termotivasi dan menambah keyakinan dan kepercayaan diri untuk mengimplementasikan pengetahuan yang diperoleh. Sebagian peserta juga sudah menerapkan pengetahuan dengan membuat produk-produk desain grafis dan berhasil membuka akun toko daringnya.

Meskipun dari aspek reaksi terhadap pelaksanaan pelatihan menunjukkan hasil yang belum cukup memuaskan, sisi positifnya adalah bahwa evaluasi ini menghasilkan masukan yang berharga untuk perbaikan kedepan. Beberapa catatan penting diperoleh antara lain perlunya mekanisme pemilihan peserta yang lebih selektif, peningkatan kualitas materi ajar dan perbaikan dalam cara instruktur mengajar agar lebih jelas dan menarik.

\section{Ucapan Terima Kasih}

Semua penulis memiliki kontribusi yang sama dalam penulisan artikel ini. Penulis mengucapkan terima kasih kepada Pimpinan BPSDMP Kominfo Jakarta yang telah mendukung terlaksanakanya penelitian ini.

\section{DAFTAR PUSTAKA}

Alimoradi, Z., Lin, C. Y., Broström, A., Bülow, P. H., Bajalan, Z., Griffiths, M. D., Ohayon, M. M., \& Pakpour, A. H. (2019). Internet addiction and sleep problems: A systematic review and meta-analysis. In Sleep Medicine Reviews (Vol. 47, pp. 51-61). W.B. Saunders Ltd. https://doi.org/10.1016/j.smrv.2019.06.004

Alwi, S. (2001). Manajemen Sumber Daya Manusia, Strategi Keunggulan Kompetitif. BPFE UGM.

APJII. (2018). Penetrasi dan Profil Perilaku Pengguna Internet Indonesia 2018.

Armstrong, M. (1991). Personnel Management Practice, Fourth Edition. Kogan Page limited.

Boyatzis, R. E. (1998). Transforming Qualitative Information. Thematic Analysis and Code Development. SAGE Publications, Inc.

Curado, C., \& Martins Teixeira, S. (2014). Training evaluation levels and ROI: The case of a small logistics company. European Journal of Training and Development, 38(9), 845-870. https://doi.org/10.1108/EJTD-05-2014-0037

De Leo, J. A., \& Wulfert, E. (2013). Problematic Internet use and other risky behaviors in college students: 
An application of problem-behavior theory. Psychology of Addictive Behaviors, 27(1), 133-141. https://doi.org/10.1037/a0030823

Dessler, G. (2008). Manajemen Sumber Daya Manusia. PT. Macanan Jaya Cemerlang.

Dhahir, D. F. (2018). Pola Asuh Penggunaan Internet di Kalangan Anak-anak Indonesia Internet Parenting upon Indonesian Children. Jurnal Pekommas, 3(2), 169-178.

Diomidous, M., Chardalias, K., Magita, A., Koutonias, P., Panagiotopoulou, P., \& Mantas, J. (2016). Social and psychological effects of the internet use. Acta Informatica Medica, 24(1), 66-69. https://doi.org/10.5455/aim.2016.24.66-69

Duerager, A., \& Livingstone, S. (2012). How can parents support children's internet safety? EU Kids Online, $1-6$.

Garavan, T. N., Morley, M., \& Gunnigle, P. (2001). Garavan, Thomas N., et al. "Human capital accumulation: the role of human resource development. Journal of European Industrial Training, 25(2/3/4), 435-448. https://doi.org/10.1108/EUM0000000005437

Gomes, F. C. (2003). Manajemen Sumber Daya Manusia. Andi Offset.

Guo, L., Luo, M., Wang, W. X., Huang, G. L., Xu, Y., Gao, X., Lu, C. Y., \& Zhang, W. H. (2018). Association between problematic Internet use, sleep disturbance, and suicidal behavior in Chinese adolescents. Journal of Behavioral Addictions, 7(4), 965-975. https://doi.org/10.1556/2006.7.2018.115

Handoko, T. H. (2001). Manajemen Personalia dan Sumber Daya Manusia. BPFE.

Harman, R. P., \& Kemp Ellington, J. (2014). Exploring Qualitative Training Reactions: Individual and Contextual Influences on Trainee Commenting. Article in Journal of Applied Psychology. https://doi.org/10.1037/a0038380

Hasibuan, M. (2007). Manajemen Sumber Daya Manusia. Bumi Aksara.

Hayes, N. (1997). Doing qualitative analysis in psychology. Psychology Press.

Irianto, A. (2011). Pendidikan sebagai Investasi dalam Pembangunan Suatu Bangsa. Kencana Prenada Media.

Ivankova, N. V., Creswell, J. W., \& Stick, S. L. (2006). Using Mixed-Methods Sequential Explanatory Design: From Theory to Practice. Field Methods, 18(1), 3-20. https://doi.org/10.1177/1525822X05282260

Lekawael, R. F. J. (2017). the Impact of Smartphone and Internet Usage on English Language Learning. English Review: Journal of English Education, 5(2), 255-262. https://doi.org/10.25134/erjee.v5i2.540

Mamun, M. A., Hossain, M. S., Siddique, A. B., Sikder, M. T., Kuss, D. J., \& Griffiths, M. D. (2019). Problematic internet use in Bangladeshi students: The role of socio-demographic factors, depression, anxiety, and stress. Asian Journal of Psychiatry, 44, 48-54. https://doi.org/10.1016/j.ajp.2019.07.005

Mondy, R. W. (2008). Manajemen sumber daya manusia. Erlangga.

Ningrum, E. (2016). Pengembangan Sumber Daya Manusia Bidang Pendidikan. Jurnal Geografi Gea, 9(1). https://doi.org/10.17509/gea.v9i1.1681

Nurbiyati, T. (2015). Evaluasi Pengembangan Sumber Daya Manusia: Sebuah Review. Jurnal Kajian Bisnis, 23(1), 52-63.

Schneider, B. H., Atkinson, L., \& Tardif, C. (2001). Child-parent attachment and children's peer relations: a quantitative review. Developmental Psychology, 37(1), 86-100. https://doi.org/10.1037/00121649.37.1.86

Sutadji. (2010). Perencanaan dan Pengembangan Sumber Daya Manusia. Dee Publish.

Tilaar, H. A. R. (1998). Beberapa Agenda Reformasi Pendidikan Nasional dalam Perspektif Abad 21. Tera Indonesia.

Yusuf, A. E., \& Suwarno. (2011). Pengembangan SDM. Universitas Terbuka. 